\title{
PENGARUH KONSENTRASI CMC DAN KONSENTRASI GLISEROL TERHADAP KARAKTERISTIK EDIBLE PACKAGING KOPI INSTAN DARI PATI KACANG HIJAU (Vigna radiata L.)
}

\author{
Thomas Gozali, Willy Pranata Wijaya, M. Iqbal Rengganis \\ Program Studi Teknologi Pangan, Fakultas Teknik, Universitas Pasundan, Jl. Dr. Setiabudhi No.193, Bandung, 40153, \\ Indonesia \\ E-mail : thomasgozaly@unpas.ac.id
}

\begin{abstract}
Abstrak
Penelitian ini bertujuan untuk mengetahui pengaruh konsentrasi CMC, konsentrasi gliserol serta interaksi keduanya terhadap karakteristik edible packaging pati kacang hijau. Penelitian ini menggunakan Rancangan Acak Kelompok (RAK) dengan pola faktorial 3x3 dengan 3 kali pengulangan. Faktor pertama adalah konsentrasi CMC (C) yang terdiri dari c1 (1\%), c2 (2\%), dan c3 (3\%). Faktor kedua adalah konsentrasi gliesrol (P) yang terdiri dari p1 (1\%), p2 (2\%), dan p3 (3\%). Respon meliputi respon organoleptik, kimia, fisik, dan uji kuat tarik, persen perpanjangan (elongasi), serta laju transmisi uap air pada sampel terpilih. Hasil penelitian menunjukkan bahwa konsentrasi CMC berpengaruh nyata terhadap kadar air, kecepatan larut, tekstur dan warna, namun tidak berpengaruh nyata terhadap kenampakan edible packaging pati kacang hijau. Konsentrasi gliserol berpengaruh nyata terhadap kadar air, kecepatan larut, dan tekstur, namun tidak berpengaruh nyata terhadap kenampakan dan warna edible packaging pati kacang hijau. Interaksi konsentrasi CMC dan konsentrasi gliserol berpengaruh nyata terhadap kadar air, kecepatan larut, dan tekstur namum tidak berpengaruh nyata terhadap kenampakan dan warna edible packaging pati kacang hijau. Hasil analisis dipilih dengan karakteristik terbaik dari edible packaging yaitu c1p2 memiliki nilai kuat tarik 2,48108 MPa, persen elongasi sebesar 70\% dan laju transmisi uap air sebesar 0,172522 (g/m2/h), c1p3 memiliki nilai kuat tarik 3,94227 MPa, persen elongasi sebesar 37\% dan laju transmisi uap air sebesar 0,195397 (g/m2/h) dan c2p2 memiliki nilai kuat tarik 1,09344 $\mathrm{MPa}$, persen elongasi sebesar $106 \%$ dan laju transmisi uap air sebesar $0,157729(\mathrm{~g} / \mathrm{m} 2 / \mathrm{h})$.
\end{abstract}

\begin{abstract}
This study aims to determine the effect of CMC concentration, glycerol concentration and the interaction of both on the edible packaging characteristics of mung bean starch. This study used a Randomized Block Design (RBD) with a factorial pattern of $3 \times 3$ with 3 repetitions. The first factor is the concentration of CMC (C) consisting of c1 (1\%), c2 $(2 \%)$, and c3 (3\%). The second factor is the concentration of gliesrol (P) consisting of p1 (1\%), p2 (2\%), and p3 (3\%). Responses include organoleptic, chemical, physical, and tensile strength tests, elongation percentages, and the rate of water vapor transmission in selected samples. The results showed that the concentration of CMC significantly affected water content, dissolved speed, texture and color, but did not significantly affect the appearance of edible packaging of mung bean starch. Glycerol concentration significantly affected water content, dissolved speed, and texture, but did not significantly affect the appearance and color of edible packaging of mung bean starch. The interaction of CMC concentration and glycerol concentration significantly affected water content, solubility speed, and texture but did not significantly affect the appearance and color of edible packaging of mung bean starch. The results of the analysis were selected with the best characteristics of edible packaging namely c1p2 having a tensile strength value of $2.48108 \mathrm{MPa}$, percent elongation of $70 \%$ and a water vapor transmission rate of $0.172522(\mathrm{~g} / \mathrm{m} 2 / \mathrm{h}), \mathrm{c} 1 \mathrm{p} 3$ had a tensile strength value of $3.94227 \mathrm{MPa}$, elongation percent by $37 \%$ and water vapor transmission rate of $0.195397(\mathrm{~g} / \mathrm{m} 2 / \mathrm{h})$ and c2p2 have tensile strength values of $1.09344 \mathrm{MPa}$, elongation percent by $106 \%$ and water vapor transmission rate of 0.157729 (g/m2/ h).
\end{abstract}

Keywords: CMC, Glycerol, Edible Packaging, Mung Beans, and Mung Bean Starch

\section{Pendahuluan}

Plastik merupakan salah satu kemasan yang banyak digunakan karena dapat menjadikan hidup manusia lebih mudah. Penggunaan plastik yang semakin meluas disebabkan oleh kelebihan yang dimilikinya, yaitu plastik mudah dibuat dalam berbagai bentuk dan ukuran, mempunyai ketahanan kimia yang tinggi, dapat diatur keelastisannya, murah, dan dapat bertahan untuk waktu yang lama. Kelebihan plastik ini pula yang menjadikan plastik sebagai salah satu polutan yang sangat besar pengaruhnya. Harga plastik yang murah membuat orang dengan mudah membuang dan menjadikannya tumpukan sampah yang sulit dihancurkan oleh alam.

Plastik yang digunakan saat ini merupakan polimer sintetis dari bahan baku minyak bumi yang terbatas jumlahnya dan tidak dapat diperbaharui. Maka, dibutuhkan adanya alternatif bahan plastik yang 
diperoleh dari bahan yang mudah didapat dan tersedia di alam dalam jumlah besar dan murah tetapi mampu menghasilkan produk dengan kekuatan yang sama yaitu bioplastik (Martaningtiyas, 2004). Bioplastik atau plastik dapat terdegradasi secara alamiah adalah plastik atau polimer yang secara alamiah dapat dengan mudah terdegradasi baik melalui serangan mikroorganisme maupun oleh cuaca (kelembaban dan radiasi sinar matahari). Cara lainnya yang dapat digunakan adalah pencampuran pati dengan selulosa, gelatin dan jenis biopolimer lainnya yang dapat memperbaiki kekurangan dari sifat plastik berbahan pati (Ban, 2006).

Edible packaging dikelompokkan menjadi dua bagian, yaitu yang berfungsi sebagai pelapis (edible coating) dan berbentuk lembaran (edible film). Edible coating banyak digunakan untuk pelapis produk ayam beku, daging beku, makanan semi basah (intermediate moisture foods), produk konfeksionari, produk hasil laut, sosis, buah-buahan dan juga obat-obatan terutama untuk pelapis kapsul (Krochta et al., 1994). Aplikasi edible packaging pati kacang hijau adalah sebagai pengemas primer untuk menguragi pengunaan pengemas berbahan non degradable.

Komponen utama penyusun edible film dibagi menjadi tiga kelompok yaitu hidrokoloid, lemak, dan komposit (Rodriguez, 2006). Salah satu bahan utama yang digunakan dalam pembuatan edible film ini yaitu pati yang termasuk kelompok hidrokoloid, yang merupakan bahan yang mudah didapat, harganya murah, serta jenisnya beragam di Indonesia (Setiani et al., 2013).

Pati terdiri atas dua jenis polimer, yakni rantai lurus D-glukan amilosa dan rantai bercabang amilopektin. Kedua jenis polimer tersebut memiliki sifat yang berbeda dalam pembentukan gel dan kristal. Amilosa dan amilopektin secara fisik membentuk ikatan silang inter- dan intramolekul untuk membentuk jaringan makromolekul yang lebih besar pada pembuatan gel (Maizura et al. 2007). Ikatan-ikatan silang yang terdapat pada jaringan makromolekul pati terutama dibentuk dari domain mikrokristal amilosa, yang berkontribusi pada kekuatan dan daya peregangan yang tinggi pada film yang dihasilkan (Rindlay-Wastling et al., 1998).

Garcia et al. (2000) melaporkan bahwa kandungan amilosa yang tinggi akan membuat film menjadi lebih kompak karena amilosa bertanggung jawab terhadap pembentukan matriks film. Menurut Krochta(1997), amilosa adalah fraksi yang berperan dalam pembentukan gel sertadapat menghasilkan lapisan tipis (film) yang baik dibandingkan amilopektin.

Kacang-kacangan dikenal sebagai bahan pangan sumber protein, namun pada kacang hijau mempunyai sifat cukup unik. Kacang hijau mengandung protein dan sekaligus pati cukup tinggi. Menurut penelitian Triwitono, P., et al., (2017), menyatakan bahwa kandungan pati kacang hijau berkisar antara 40,41$43,46 \%$ bk dengan rendemen pati bervariasi antara 26 $36,76 \%$. Beberapa faktor yang berpengaruh terhadap hasil rendemen tersebut antara lain metode ekstraksi, frekuensi deproteinasi, tingkat kebersihan penghilangan kulit, dan teknik pemisahan residu dari endapan pati. Selain itu kemungkinan juga disebabkan oleh perbedaan varietas, iklim, unsur hara tanah serta daerah asal tempat tumbuhnya (Asaoka dkk., 1985; Morrison dan Azudin, 1987). Kadar amilosa pada kacang hijau varietas lokal berkisar antara 53,70-55,39\% bk. Hasil ekstraksi pati kacang hijau mempunyai kemurnian pati sangat tinggi (berkisar 99,22 - 99,80\%) dengan kadar abu dan lemak sangat rendah.

Kopi instan, juga disebut dengan kopi cepat saji dan kopi bubuk, adalah minuman yang berasal dari biji kopi yang diseduh. Kopi instan pada umumnya diproduksi untuk tujuan komersial, baik melalui pengeringan beku atau pengeringan semprot, dan setelah itu bisa direhidrasi.

Kopi bubuk ketika disimpan pada tempat yang terbuka atau tanpa hampa udara setelah 2-3 minggu akan terjadinya kehilangan aroma khas kopi. Ketengikan yang terjadi disebabkan karena adanya antara oksigen yang terdapat dalam udara dan lemak yang berada pada biji kopi. Kehilangan aroma pada kopi bubuk adanya penguapan zat kafeol yang beraroma khas kopi (Setyani, 2002).

Edible coating/film berbahan dasar polisakarida berperan sebagai membran permeabel yang selektif terhadap pertukaran gas $\mathrm{O} 2$ dan $\mathrm{CO} 2$ sehingga dapat menurunkan tingkat respirasi pada buah dan sayuran (Krochta et al.1994). Aplikasi coating polisakarida dapat mencegah dehidrasi, oksidasi lemak, dan pencoklatan pada permukaan serta mengurangi laju respirasi dengan mengontrol komposisi gas $\mathrm{CO} 2$ dan $\mathrm{O} 2$ dalam atmosfer internal. Keuntungan lain coating berbahan dasar polisakarida adalah memperbaiki flavor, tekstur, dan warna, meningkatkan stabilitas selama penjualan dan penyimpanan, memperbaiki penampilan, dan mengurangi tingkat kebusukan. Pemanfaatan dari senyawa yang berantai panjang ini sangat penting karena tersedia dalam jumlah yang banyak, harganya murah, dan bersifat nontoksik. (Krochta et al. 1994).

Kelebihan edible film yang dibuat dari hidrokoloid diantaranya memiliki kemampuan yang baik untuk melindungi produk terhadap oksigen, karbondioksida, dan lipid serta memiliki sifat mekanis yang diinginkan dan meningkatkan kesatuan struktural produk. Kelemahannya, film dari karbohidrat kurang bagus digunakan untuk mengatur migrasi uap air sementara film dari protein sangat dipengaruhi oleh perubahan $\mathrm{pH}$. Kelebihan edible film dari lipid adalah memiliki kemampuan yang baik untuk melindungi produk dari penguapan air. Sedangkan kekurangannya yaitu kegunaannya dalam bentuk murni sebagai pelapis masih terbatas, karena mempunyai kekurangan dari segi ketahanannya. Edible film dari komposit (gabungan hidrokoloid dan lipid) dapat meningkatkan kelebihan film dari hidrokoloid dan film dari lipid, serta mengurangi kelemahannya. Pembentukkan edible film 
merupakan proses pertumbuhan fragmen-fragmen kecil yang akan membentuk suatu polimer. Perinsip pembentukkan edible film adalah interaksi rantai polimer menghasilkan polimer yang lebih besar dan stabil (Syamsir, 2008). Pati kacang hijau dipilih sebagai bahan baku pembuatan edible packaging kopi instan dikarenakan mudah didapat, murah serta kandungan amilosa pada kacang hijau cukup tinggi sehingga dapat meningkatkan kelarutan dalam air, sedangkan protein kacang hijau yaitu isoflavon memiliki sifat sukar larut dalam air. Oleh karena itu pati kacang hijau sangat berpotensi untuk digunakan sebagai bahan baku edible packaging yang sesuai untuk kopi instan.

Plasticizer merupakan bahan yang ditambahkan ke dalam suatu bahan pembentuk film untuk meningkatkan fleksibilitasnya, karena dapat menurunkan gaya intermolekuler sepanjang rantai polimernya, sehingga film akan lentur ketika dibengkokkan (Garcia et al. dalam Rodriguez et al, 2006). Menurut Damat (2008), karakteristik fisik edible film dipengaruhi oleh jenis bahan serta jenis dan konsentrasi plasticizer.

Penambahan bahan penstabil bertujuan untuk memperbaiki sifat-sifat fisik dari edible film yang akan dihasilkan. Penstabil yang banyak digunakan salah satunya adalah Carboxy Methyl Cellulose (CMC). CMC merupakan bahan penstabil yang memiliki daya ikat yang kuat dan berperan untuk meningkatkan kekentalan dan memperbaiki tekstur pembentuk film.

\section{Bahan dan Metode Penelitian}

Bahan baku utama yang digunakan dalam penelitian ini adalah kacang hijau varietas murai yang diperoleh dari Balai Penelitian Tanaman Aneka Kacang dan Umbi atau Balitkabi, kopi instan komersil, aquadest, gliserol, sorbitol, lilin lebah/beeswax, dan CMC.

Metode penelitian dilakukan dalam dua tahap yaitu penelitian pendahuluan dan penelitian utama. Penelitian pendahuluan yang akan dilakukan adalah analisis kadar pati dan kadar air pada pati kacang hijau. Kemudian penentuan plasticizer terpilih dengan pengujian tensile strength, persen elongasi dan kecepatan larut.

Penelitian utama yang akan dilakukan merupakan lanjutan dari penelitian pendahuluan meliputi rancangan perlakuan, rancangan percobaan, rancangan analisis dan rancangan respon.

Rancangan perlakuan terdiri dari dua faktor yaitu konsentrasi CMC (C) dan konsentrasi gliserol (P) terhadap pembuatan edible packaging pati kacang hijau yang terdiri dari 3 taraf. Faktor konsentrasi CMC (C) terdiri dari 3 taraf, yaitu $\mathrm{c} 1=1 \%, \mathrm{c} 2=2 \%, \mathrm{c} 3=3 \%$. Faktor konsentrasi gliserol (P) terdiri dari 3 taraf, yaitu $\mathrm{p} 1=1 \%, \mathrm{p} 2=2 \%, \mathrm{p} 3=3 \%$

Model rancangan percobaan yang digunakan dalam pembuatan edible packaging pati kacang hijau adalah rancangan faktorial $3 \times 3$ dalam rancangan acak kelompok (RAK) dengan 3 kali pengulangan, sehingga diperoleh 27 satuan perlakuan
Rancangan respon meliputi respon fisik, kimia, dan organoleptik. Respon fisik yang dilakukan yaitu dan kecepatan larut. Respon kimia yang dilakukan meliputi: analisis kadar air dengan metode gravimetri (AOAC, $945.15,2000)$. Respon organoleptik yang digunakan adalah metode uji mutu hedonik yang dilakukan untuk mengetahui tingkat mutu dan penerimaan panelis terhadap mutu edible packaging sehingga diketahui produk disukai atau tidak oleh panelis. Uji organoleptik ini dapat menentukan suatu produk diterima atau tidak oleh konsumen yang diwakili oleh panelis sebagai penilaian sebanyak 30 panelis. Uji organoleptik yang digunakan meliputi tekstur (keelastisan), kenampakan (halus atau kasar) dan warna (cerah atau gelap).

Pada sampel terpilih dilakukan pengujian secara fisik yaitu tensile strength, persen elongasi, serta laju transmisi uap air (WVTR). Kemudian dilakukan analisis kadar air pada kopi instan dengan dan tanpa edible packaging terpilih sebelum dan setelah 24 jam.

\section{Hasil dan Pembahasan \\ Penelitian Pendahuluan}

Penelitian pendahuluan yang dilakukan yaitu pembuatan pati kacang hijau, uji kadar air, uji kadar pati serta pemilihan jenis plasticizer terbaik yang digunakan pada penelitian utama. Plasticizer yang digunakan yaitu gliserol, sorbitol, dan lilin lebah dengan konsentrasi sebanyak $2 \%$ dan penambahan penstabil CMC sebanyak $2 \%$. Edible film yang dihasilkan dianalisis dengan salah satu respon uji yaitu analisis kuat tarik dan persen perpanjangan (elongasi), lalu edible film dengan nilai kuat tarik serta persen elongasi terbaik dipilih untuk digunakan dalam penelitian utama.

Analisis bahan baku dilakukan untuk mengetahui kadar pati yang terdapat pada pati kacang hijau yang akan digunakan sebagai bahan baku dalam pembuatan edible packaging pati kacang hijau.

Data hasil perhitungan analisis bahan baku didapat bahwa bahan baku pati kacang hijau mengandung pati sebesar $87,59 \%$. Hasil tersebut menunjukkan bahwa kacang hijau sangat potensial untuk dimanfaatkan sebagai produk pangan yang membutuhkan sumber pati yang tinggi.

Analisis kadar air pati kacang hijau dilakukan untuk mengetahui kadar air yang pada pati kacang hijau setelah dilakukan pengeringan telah memenuhi syarat mutu yang telah ditentukan.

Data hasil perhitungan analisis kadar air pati kacang hijau didapat bahwa pati kacang hijau memiliki kadar air sebesar 5,5\%. Hasil dari penelitian terdahulu menunjukkan bahwa kadar air pati kacang hijau sebesar 15,97\% (Jayeng Laga, 2017).

\section{Penelitian Utama}

Penelitian utama dilakukan untuk mengetahui pengaruh konsentrasi $\mathrm{CMC}$, konsentrasi plasticizer terpilih yaitu gliserol serta interaksi antara konsentrasi CMC dan konsentrasi gliserol terhadap karakteristik 
edible packaging pati kacang hijau. Penelitian utama menggunakan respon yang diuji yaitu analisis kimia (kadar air), analisis fisik (kecepatan larut), dan pengujian organoleptik (tekstur, kenampakan dan warna). Formulasi yang terpilih dari pengujian kimia, fisik, organoleptik akan dilakukan analisis kuat tarik, elongasi, laju transmisi uap air, serta pengujian kimia (kadar air) pada produk kopi instan dengan dan tanpa menggunakan edible packaging.

\section{Respon Kimia}

\section{a. Kadar Air}

Air merupakan komponen penting dalam bahan makanan karena air dapat mempengaruhi penampakan, tekstur, serta cita rasa dan umur simpan dari makanan itu sendiri. Untuk memperpanjang daya simpan suatu bahan sehingga bahan menjadi lebih awet maka sebagian air dalam bahan harus dihilangkan dengan beberapa cara, umumnya dilakukan pengeringan baik pengeringan alami maupun pengeringan buatan (Winarno, 2004).

Hasil analisis variansi (ANAVA) terhadap kadar air edible packaging pati kacang hijau dapat diketahui bahwa faktor konsentrasi CMC (C), konsentrasi plasticizer (P) serta interaksi antara konsentrasi CMC dan konsentrasi plasticizer (CP) memberikan pengaruh nyata terhadap kadar air edible packaging pati kacang hijau.

Tabel 1. Pengaruh Interaksi Konsentrasi CMC (C) dan Konsentrasi Plasticizer (P) Terhadap Kadar Air (\%) Edible Packaging Pati Kacang Hijau

\begin{tabular}{|c|c|c|c|}
\hline \multirow{2}{*}{$\begin{array}{c}\text { Konsentrasi } \\
\text { CMC (C) (\%) }\end{array}$} & \multicolumn{3}{|c|}{$\begin{array}{c}\text { Konsentrasi Gliserol } \\
(\mathrm{P})(\%)\end{array}$} \\
\hline & $\mathrm{p} 1(1 \%)$ & $\mathrm{p} 2(2 \%)$ & p3 (3\%) \\
\hline c1 $(1 \%)$ & $\begin{array}{ll}3,17 & \mathrm{~A} \\
\mathrm{a} & \end{array}$ & $\begin{array}{ll}4,83 & \mathrm{~A} \\
\mathrm{~b} & \end{array}$ & $\begin{array}{ll}5,00 & \mathrm{~A} \\
\mathrm{~b} & \end{array}$ \\
\hline $\mathrm{c} 2(2 \%)$ & $\begin{array}{ll}5,92 & B \\
\mathrm{a} & \\
\end{array}$ & $\begin{array}{ll}6,00 & B \\
a & \end{array}$ & $\begin{array}{ll}6,17 & \text { B } \\
\mathrm{a} & \\
\end{array}$ \\
\hline c3 $(3 \%)$ & $\begin{array}{ll}6,33 & \mathrm{C} \\
\mathrm{a} & \end{array}$ & $\begin{array}{ll}6,42 & \mathrm{C} \\
\mathrm{a} & \end{array}$ & $\begin{array}{l}6,83 \quad \mathrm{C} \\
\mathrm{b}\end{array}$ \\
\hline
\end{tabular}

Keterangan : Setiap nilai rata-rata yang diikuti huruf berbeda menyatakan perbedaan nyata menurut uji Duncan pada taraf nyata $5 \%$. (Huruf kecil dibaca horizontal, huruf besar dibaca vertikal).

Berdasarkan Tabel 1, dapat diketahui bahwa semakin meningkat konsentrasi CMC dan konsentrasi plasticizer berpengaruh terhadap kadar air dari edible packaging yang dihasilkan. Hal ini dikarenakan penambahan CMC yang memiliki kemampuan mengikat air yang tinggi. Semakin banyak konsentrasi CMC yang ditambahkan maka semakin besar pula jumlah air yang terikat pada edible packaging pati kacang hijau yang akan menaikkan kadar air dari edible packaging itu sendiri.

Menurut Manab (2008), faktor lain dari peningkatan kadar air adalah dengan penambahan gliserol yang merupakan golongan lemak. Penambahan lemak dengan konsentrasi yang tinggi dapat meningkatkan kadar air dari edible packaging.

\section{b. Kecepatan Larut}

Kelarutan dalam air yaitu untuk memprediksi kestabilan edible film terhadap pengaruh air. Hasil analisis menunjukkan bahwa dengan adanya penambahan masing-masing variasi komposisi mempengaruhi sifat fisik kelarutan dalam air. Besarnya kelarutan suatu zat dalam suatu pelarut dipengaruhi oleh sifat dan intensitas kekuatan serta interaksi antara zat terlarut dan pelarutnya (Nurhayati et al., 2012).

Kelarutan edible film merupakan faktor yang sangat penting pada bahan pengemas. Kelarutan dipengaruhi oleh komponen hidrofilik dan hidrofobik. Komponen hidrofilik adalah komponen yang suka air atau larut dalam air, dalam penelitian ini sorbitol dan CMC adalah komponen yang mudah larut dalam air. hal ini sesuai dengan pernyataan (Nugroho, 2013).

Perhitungan statistik menunjukkan hasil perlakuan konsentrasi CMC (C), konsentrasi plasticizer (P), dan interaksi $(\mathrm{CP})$ memberikan pengaruh nyata terhadap kecepatan larut edible packaging pati kacang hijau, seperti yang dilihat pada Tabel 2 .

\begin{tabular}{|c|c|c|c|c|c|c|}
\hline \multirow{2}{*}{$\begin{array}{c}\text { Konsentrasi } \\
\text { CMC (C) (\%) }\end{array}$} & \multicolumn{5}{|c|}{ Konsentrasi Gliserol } \\
\cline { 2 - 7 } & \multicolumn{2}{|c|}{$\mathrm{p} 1(1 \%)$} & \multicolumn{2}{c|}{$\mathrm{p} 2(2 \%)$} & \multicolumn{2}{c|}{$\mathrm{p} 3(3 \%)$} \\
\hline \multirow{2}{*}{$\mathrm{c} 1(1 \%)$} & 0,0135 & $\mathrm{~B}$ & 0,0130 & $\mathrm{~B}$ & 0,0112 & $\mathrm{~B}$ \\
\cline { 2 - 7 } & $\mathrm{c}$ & & $\mathrm{b}$ & $\mathrm{a}$ & \\
\hline \multirow{2}{*}{$\mathrm{c} 2(2 \%)$} & 0,0139 & $\mathrm{C}$ & 0,0187 & $\mathrm{C}$ & 0,0119 & $\mathrm{C}$ \\
\cline { 2 - 7 } & $\mathrm{b}$ & & $\mathrm{c}$ & & $\mathrm{a}$ & \\
\hline \multirow{2}{*}{$\mathrm{c} 3(3 \%)$} & 0,0094 & $\mathrm{~A}$ & 0,0091 & $\mathrm{~A}$ & 0,0087 & $\mathrm{~A}$ \\
\cline { 2 - 7 } & $\mathrm{c}$ & $\mathrm{b}$ & $\mathrm{a}$ & \\
\hline
\end{tabular}

Tabel 2. Pengaruh Interaksi Konsentrasi CMC (C) dan Konsentrasi Plasticizer (P) Terhadap Kecepatan Larut (g/dtk) Edible Packaging Pati Kacang Hijau

Keterangan : Setiap nilai rata-rata yang diikuti huruf berbeda menyatakan perbedaan nyata menurut uji Duncan pada taraf nyata 5\%. (Huruf kecil dibaca horizontal, huruf besar dibaca vertikal).

Berdasarkan Tabel 2, dapat diketahui bahwa konsentrasi CMC $1 \%$ berpengaruh terhadap konsentrasi gliserol $1 \%$ dan $2 \%$, konsentrasi CMC $2 \%$ berpengaruh terhadap konsentrasi gliserol $1 \%$ dan $2 \%$, konsentrasi CMC $3 \%$ berpengaruh terhadap konsentrasi gliserol $1 \%$ dan 2\%. Pada konsentrasi CMC 3\% nilai kecepatan larutan edible menurun dikarenakan semakin banyak CMC yang ditambahkan makan membutuhkan air yang lebih banyak untuk melarutkannya sehingga dengan jumlah air yang ditambahkan sebanyak $100 \mathrm{ml}$ edible packaging dengan CMC 3\% lebih lama untuk larut dalam air

Menurut Bourtoom (2007), jenis dan konsentrasi dari pemlastis yang digunakan akan memberikan pengaruh terhadap kelarutan dari film berbahan dasar pati. 


\section{Respon Organoleptik}

Respon organoleptik yang digunakan adalah metode uji mutu hedonik yang dilakukan untuk mengetahui tingkat mutu dan penerimaan panelis terhadap mutu edible packaging sehingga diketahui produk disukai atau tidak oleh panelis. Uji organoleptik ini dapat menentukan suatu produk diterima atau tidak oleh konsumen yang diwakili oleh panelis sebagai penilaian sebanyak 30 panelis. Uji organoleptik yang digunakan meliputi tekstur (keelastisan), kenampakan (halus atau kasar) dan warna (cerah atau gelap).

a. Tesktur

Berdasarkan hasil perhitungan analisis variansi (ANAVA) menunjukan bahwa konsentrasi CMC (C) dan konsentrasi plasticizer $(\mathrm{P})$, serta interaksinya $(\mathrm{CP})$ berpengaruh nyata terhadap atribut tekstur edible packaging pati kacang hijau.

Tabel 3 Pengaruh Interaksi Konsentrasi CMC (C) dan Konsentrasi Plasticizer (P) Terhadap Atribut Tekstur Edible Packaging Pati Kacang Hijau

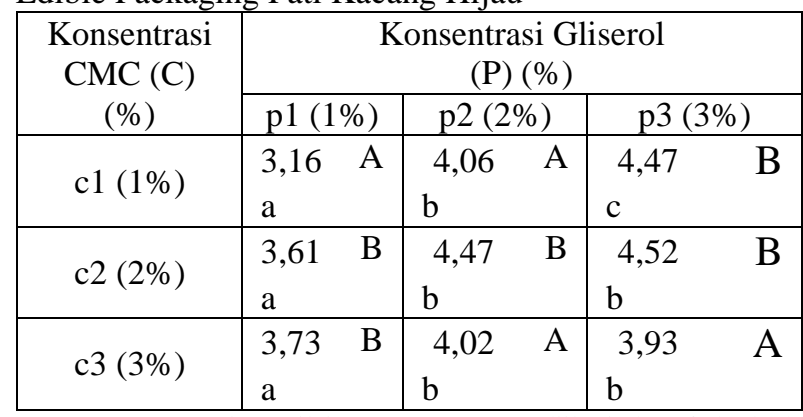

Keterangan : Setiap nilai rata-rata yang diikuti huruf berbeda menyatakan perbedaan nyata menurut uji Duncan pada taraf nyata $5 \%$. (Huruf kecil dibaca horizontal, huruf besar dibaca vertikal).

Tabel 3 menunjukkan bahwa pada perlakuan c1p3 yang merupakan faktor (C) konsentrasi CMC (1\%) dan faktor $(\mathrm{P})$ konsentrasi gliserol sebesar $(3 \%)$ dan $\mathrm{c} 2 \mathrm{p} 2$ yang merupakan faktor $(\mathrm{C})$ konsentrasi CMC (2\%) dan faktor $(\mathrm{P})$ konsentrasi gliserol sebesar $(2 \%)$ menunjukan hasil tertinggi pada pengujian organoleptik atibut tekstur, hal ini dikarenakan konsentrasi CMC dan konsentrasi gliserol yang dapat mempengaruhi tektur dari edible packaging pati kacang hijau. Semakin tinggi konsentrasi gliserol menunjukkan semakin besar angka mutu hedonik yang artinya semakin lentur edible packaging. Pada berbagai konsentrasi gliserol semakin tinggi konsentrasi penstabil CMC menunjukkan semakin kecil angka mutu hedonik yang artinya semakin kurang kelenturan dari edible packaging. Hal tersebut dikarenakan salah satu dari sifat CMC adalah mengikat dan membentuk suspensi dalam air. Semakin tinggi kadar CMC, pembentukan ikatan silang semakin besar dan immobilisasi molekul pelarut juga semakin tinggi sehingga menyebabkan kecenderungan viskositas meningkat. Ikatan silang yang dihasilkan oleh CMC membuat matriks edible packaging semakin kuat dan menghasilkan edible packaging yang semakin baik teksturnya. Semakin banyak konsentrasi CMC yang ditambahkan maka semakin kaku dan rapuh (kurang lentur) edible packaging yang dihasilkan (Indriyati, 2006).

b. Kenampakan

Berdasarkan hasil perhitungan analisis variansi (ANAVA) menunjukan bahwa konsentrasi CMC (C) dan konsentrasi plasticizer $(\mathrm{P})$, serta interaksinya (CP) tidak berpengaruh nyata terhadap atribut kenampakan edible packaging pati kacang hijau.

CMC dan gliserol serta interaksiya tidak memberikan pengaruh nyata terhadap kenampakan karena CMC merupakan derivat selulosa yang sifatnya mengikat air dan sering digunakan sebagai pembentuk halus (Sanderson, 1994). Penambahan jenis penstabil CMC serta plastisizer gliserol tidak mempengaruhi kenampakan halus atau kasar pada edible packaging dikarenakan gliserol berbentuk cair dan CMC akan membentuk gel yang tidak memiliki kenampakan halus atau kasar.

Pati kacang hijau dalam atribut ini menjadi satusatunya faktor yang dapat menimbulkan kenampakan berupa halus atau kasar, namun dikarenakan pati yang digunakan semua memiliki ukuran partikel yang seragam yaitu sebesar 100 mesh maka edible packaging pati kacang hijau yang dihasilkan pun memiliki kenampakan yang halus.

c. Warna

Berdasarkan hasil perhitungan analisis variansi (ANAVA) menunjukan bahwa konsentrasi CMC (C) berpengaruh nyata terhadap atribut kenampakan edible packaging pati kacang hijau, sedangkan konsentrasi plasticizer (P), serta interaksinya (CP) tidak berpengaruh nyata terhadap atribut kenampakan edible packaging pati kacang hijau yang dihasilkan.

Tabel 4 Pengaruh Interaksi Konsentrasi CMC (C) Warna Edible Packaging Pati Kacang Hijau

\begin{tabular}{|c|c|c|}
\hline Perlakuan & $\begin{array}{c}\text { Rata-Rata } \\
\text { Perlakuan }\end{array}$ & $\begin{array}{c}\text { Taraf } \\
\text { Nyata 5\% }\end{array}$ \\
\hline c3 3\% & 1,951 & $\mathrm{a}$ \\
\hline $\mathrm{c} 11 \%$ & 2,204 & $\mathrm{~b}$ \\
\hline $\mathrm{c} 22 \%$ & 2,242 & $\mathrm{~b}$ \\
\hline
\end{tabular}

Keterangan : huruf yang sama pada kolom taraf nyata 5\% menunjukkan tidak berbeda nyata, sedangkan huruf yang berbeda pada kolom taraf nyata $5 \%$ menunjukkan berbeda nyata.

Tabel 4 menunjukkan konsentrasi CMC pada setiap taraf memberikan perbedaan nyata terhadap atribut warna edible packaging pati kacang hijau. Konsentrasi CMC (2\%) memiliki penilaian yang lebih tinggi dibandingkan dengan perlakuan c1 konsentrasi CMC (1\%) dan c3 konsentrasi CMC (3\%). Hal ini disebabkan semakin banyak konsentrasi penstabil CMC yang ditambahkan semakin menurunkan mutu hedonik terhadap warna edible packaging pati kacang hijau 
karena edible packaging pati kacang hijau yang terbentuk akan berwarna kekuningan cenderung gelap dan lebih lembek. Dalam hal ini kemungkinan warna yang berbeda dipengaruhi oleh adanya pati dan CMC yang terkena panas saat pengeringan. Warna paling cepat dan mudah memberi kesan tetapi paling sulit diberi deskripsi dan sulit cara pengukurannya karena penilaiannya secara subjektif, yaitu dengan penglihatan sangat menentukan dalam penilaian komoditi (Soekarto, 1985).

Berdasarkan hasil respon organoleptik meliputi tekstur, kenampakan, dan warna, respon kimia yaitu kadar air, serta respon fisik yaitu pengujian kecepatan larut. Perlakuan yang terpilih mengacu pada karakteristik edible packaging pati kacang hijau yang diinginkan. Berdasarkan Tabel 5 hasil perhitungan metode skoring maka dapat diambil suatu kesimpulan untuk menentukan sampel terpilih dari penelitian ini adalah sebagai berikut.

Tabel 5. Penentuan Sampel Terpilih Metode Skoring

\begin{tabular}{|c|c|c|c|c|}
\hline $\begin{array}{c}\text { Kode } \\
\text { sampel }\end{array}$ & $\begin{array}{c}\text { Kadar } \\
\text { Air }\end{array}$ & $\begin{array}{c}\text { Kec. } \\
\text { Larut }\end{array}$ & $\begin{array}{c}\text { Organoleptik } \\
\text { (warna, } \\
\text { tekstur, } \\
\text { kenampakan) }\end{array}$ & Jumlah \\
\hline c1p1 & 5 & 3 & 2 & 10 \\
\hline c1p2 & 3 & 3 & 4 & $\mathbf{1 0}$ \\
\hline c1p3 & 3 & 2 & 5 & $\mathbf{1 0}$ \\
\hline c2p1 & 2 & 3 & 3 & 8 \\
\hline c2p2 & 2 & 5 & 5 & $\mathbf{1 2}$ \\
\hline c2p3 & 1 & 2 & 5 & 8 \\
\hline c3p1 & 1 & 1 & 1 & 3 \\
\hline c3p2 & 1 & 1 & 2 & 4 \\
\hline c3p3 & 1 & 1 & 1 & 3 \\
\hline
\end{tabular}

Berdasarkan hasil metode skoring bahwa sampel yang terpilih adalah perlakuan c1p2, c1p3, dan c2p2. Sampel terpilih kemudian dilakukan analisis kuat tarik, elongasi, dan laju transmisi uap air untuk mengetahui respon fisik dan mekanik terhadap edible packaging pati kacang hijau. Selain itu dilakukan pengaplikasian untuk kemasan kopi instan kemudian dilakukan pengujian secara kimia (kadar air) terhadap kopi instan dengan dan tanpa menggunakan edible packaging.

3. Respon Fisik

a. Kuat Tarik dan Persen Perpanjangan (Elongasi) Sampel Terpilih

Pengujian kuat tarik (tensile streength) dilakukan untuk mengetahui besarnya gaya yang diperlukan untuk mencapai tarik maksimum pada setiap luas area film. Sifat kuat tarik tergantung pada konsentrasi dan jenis bahan penyusun edible packaging terutama sifat kohesi struktural. Kohesi struktural adalah kemampuan polimer untuk menentukan kuat atau tidak ikatan antar rantai molekul antar rantai polimer (Nasution, 2014).

Kuat tarik dan pemanjangan (elongasi) merupakan salah satu sifat yang penting bagi edible packaging. Sifat mekanik kuat tarik dinyatakan dengan kemampuan edible packaging untuk menahan tarikan atau beban maksimum ketika dilakukan pengujian. Pengujian kuat tarik dilakukan bersama dengan pengukuran nilai pemanjangan atau persen elongasi. Pemanjangan menyatakan kemampuan suatu edible packaging untuk meregang atau pertambahan panjang bahan dari panjang awal sebelum penarikan hingga putus (Nasution, 2014).

Tabel 6. Hasil Uji Kuat Tarik dan Elongasi Sampel Terpilih

\begin{tabular}{|c|c|c|c|}
\hline No. & Sampel & $\begin{array}{c}\text { Kuat Tarik } \\
(\mathrm{MPa})\end{array}$ & $\begin{array}{c}\text { Elongasi } \\
(\%)\end{array}$ \\
\hline 1 & $\mathrm{c} 1 \mathrm{p} 2$ & 2,48108 & 70 \\
\hline 2 & $\mathrm{c} 1 \mathrm{p} 3$ & 3,94227 & 37 \\
\hline 3 & $\mathrm{c} 2 \mathrm{p} 2$ & 1,09344 & 106 \\
\hline
\end{tabular}

Pada Tabel 6 didapat hasil kuat tarik untuk sampel c1p2 sebesar 2,48108 $\mathrm{MPa}, \mathrm{c} 1 \mathrm{p} 3$ sebesar $3,94227 \mathrm{MPa}$ dan c2p2 sebesar $1,09344 \mathrm{MPa}$, hasil elongasi untuk sampel c1p2 sebesar $70 \%$, c1p3 sebesar $37 \%$, dan c2p2 sebesar $106 \%$. Hasil kuat tarik sampel c1p3 sudah memenuhi standar minimal kuat tarik yang telah ditetapkan oleh Japanese Industrial Standart (1975), yaitu memiliki kuat tarik minimal 3,92 $\mathrm{MPa}$ (40kgf/cm2), sedangkan sampel c1p2 dan c2p2 belum memenuhi nilai minimal kuat tarik yang telah ditetapkan oleh Japanese Industrial Standart (1975). Hasil elongasi sampel c1p2 dan c2p2 telah memenuhi standar nilai elongasi edible film menurut Japanese Industrial Standart (1975), dimana edible film minimal memiliki nilai elongasi sebesar $70 \%$, sedangkan sampel c1p3 belum memenuhi standar nilai elongasi menurut Japanese Industrial Standart (1975).

Penambahan CMC dengan konsentrasi yang semakin tinggi akan mempengaruhi pula kuat tarik karena CMC tergolong dalam polisakarida yang membuat edible packaging menjadi semakin kompak. Penelitian lain tentang edible packaging dari pati jahe emprit menyatakan bahwa polisakarida dapat berfungsi dalam menjaga kekompakan dan kestabilan edible packaging. Semakin banyak polisakarida penyusunnya maka akan meningkatkan kekuatan peregangan sehingga kemampuan untuk meregang semakin besar dan tahan terhadap kepatahan (Nasaputra, 2012).

Gliserol sebagai plastisizer secara efektif mengurangi ikatan hidrogen internal dengan berikatan dengan gugus hidroksil pada amilopektin. Ikatan hidrogen yang semakin berkurang dapat menyebabkan 
jarak antar molekul semakin merenggang sehingga kekuatan film akan berkurang (McHugh et al., 1994).

\section{b. Transmisi Uap Air Sampel Terpilih}

Laju transmisi uap air atau water vapor transmision rate (WVTR) didefinisikan sebagai besarnya laju alir uap air melewati suatu unit area pada waktu dan kondisi tertentu (ASTM, 1980). Pengukuran nilai WVTR suatu bahan merupakan faktor yang penting dalam menilai permeabilitas bahan edible packaging terhadap uap air.

Laju transmisi uap air pada edible packaging pati kacang hijau memiliki nilai yang cukup baik yaitu sampel c1p2 memiliki WVTR sebesar sebesar 0,172522 g/m2.jam, sampel c1p3 sebesar 0,195397 $\mathrm{g} / \mathrm{m} 2$.jam dan c2p2 sebesar 0,157729 g/m2.jam Nilai batas standar maksimal laju transmisi uap air yaitu 0,42g/m2/h (Japanese Industrial Standart, 1975). Film yang mempunyai laju transmisi uap air yang kecil cocok digunakan untuk mengemas produk yang mempunyai kelembaban tinggi. Film tersebut akan menghambat jumlah uap air yang dikeluarkan produk ke luar lingkungan sehingga produk tersebut tidak cepat kering. Edible film juga dapat melindungi produk dari uap air yang masuk dari lingkungan, sehingga kontaminasi dari uap dari pertambahan kelembaban produk dapat dihindari.

Laju transmisi uap air merupakan jumlah uap air yang hilang per satuan waktu dibagi dengan luas area film. Oleh karena itu salah satu fungsi edible packaging adalah untuk menahan migrasi uap air maka permeabilitasnya terhadap uap air harus serendah mungkin (Gontard, 1993).

Tabel 7. Laju Transmisi Uap Air Pada Sampel Terpilih Sampel

\begin{tabular}{|c|c|c|c|}
\hline Sampel & $\begin{array}{c}\text { Luas } \\
\left(\mathbf{m}^{2}\right)\end{array}$ & Slope & $\begin{array}{c}\text { WVTR } \\
\left(\mathbf{g} / \mathbf{m}^{2} \text {.jam }\right)\end{array}$ \\
\hline $\mathrm{c} 1 \mathrm{p} 2$ & 0,003312 & $-0,00057$ & 0,172522 \\
\hline $\mathrm{c} 1 \mathrm{p} 3$ & 0,00329 & $-0,00064$ & 0,195397 \\
\hline $\mathrm{c} 2 \mathrm{p} 2$ & 0,00317 & $-0,0005$ & 0,157729 \\
\hline
\end{tabular}

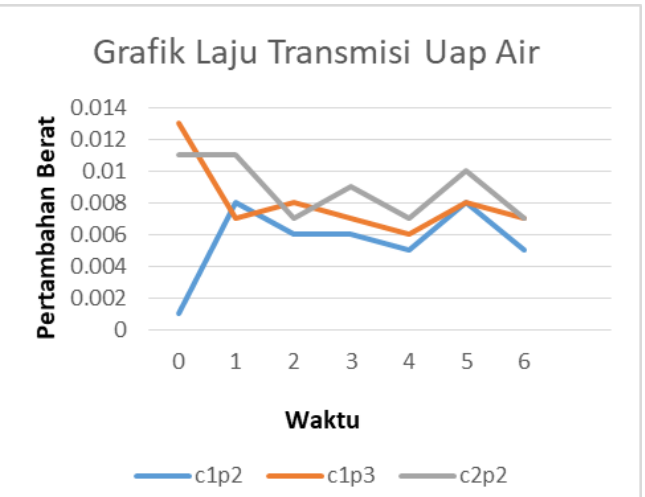

Gambar 1. Grafik Laju Transmisi Uap Air Edible Packaging Pati Kacang Hijau
Laju transmisi uap air edible packaging film dipengaruhi bahan baku yang digunakan, gabungan atau kombinasi bahan penyusun dan ketebalan edible packaging. Menurut Roy, dkk (2000) di dalam Mindarwati (2006), nilai ketebalan mempengaruhi nilai laju trasmisi uap air yang memiliki hubungan yang berbanding terbalik dengan nilai ketebalan film. Ketebalan film dapat menggambarkan jarak yang ditempuh oleh uap air berdifusi melewati film. Sehingga semakin tebal edible packaging, maka jarak yang ditempuh uap air untuk berdifusi melewati film akan semakin jauh.

Menurut McHugh dan Krochta (1994), laju transmisi uap air suatu bahan dipengaruhi oleh sifat kimia dan struktur bahan pembentuk, konsentrasi plasticizer dan kondisi lingkungan seperti kelembaban dan temperatur. Namun pada penelitian ini, semua kondisi selain konsentrasi bahan pembentuk diusahakan sama, sehingga perbedaan nilai laju transmisi uap air tersebut berasal dari perbedaan konsentrasi yang digunakan.

\section{Pengujian Kopi Instan}

a. Kadar Air

Clifford (1985), menyatakan bahwa kadar air pada kopi yang telah disangrai dan kopi instan umumnya mengandung kadar air yang tidak melebihi $4 \%$ pada suhu $20 \mathrm{oC}$, dan memiliki aw berkisar antara $0.1-0.3$. Clifford (1985), juga menjelaskan bahwa pengetahuan tentang kadar air pada kopi instan sangat diperlukan. Hal ini dikarenakan kadar air akan mempengaruhi nilai aw dan stabilitas produk selama penyimpanan, kadar air merupakan parameter dalam pengawasan proses pengeringan dan ekstraksi kopi, kadar air terkadang juga digunakan sebagai titik standar mutu pada beberapa negara dan peraturan internasional untuk produk kopi. Kadar air merupakan karakteristik penting pada produk kopi instan.

Kadar air pada kopi instan yang disimpan akan terus bertambah dengan bertambahnya waktu penyimpanan. Kadar air yang terus bertambah dapat menyebabkan kerusakan pada produk kopi instan yang ditandai dengan penggumpalan produk.

Tabel 8. Hasil Analisis Kadar Air Pada Kopi Instan

\begin{tabular}{|c|c|c|c|c|}
\hline No & Sampel & $\begin{array}{c}\text { Kadar Air } \\
\text { Tanpa Edible } \\
\text { Packaging 0 } \\
\text { jam }\end{array}$ & $\begin{array}{c}\text { Kadar Air } \\
\text { Tanpa Edible } \\
\text { Packaging } \\
24 \text { jam }\end{array}$ & $\begin{array}{c}\text { Kadar Air } \\
\text { Dengan } \\
\text { Edible } \\
\text { Packaging } \\
24 \text { jam }\end{array}$ \\
\hline 1 & $\mathrm{c} 1 \mathrm{p} 2$ & $3,5 \%$ & $8 \%$ & $6 \%$ \\
\hline 2 & $\mathrm{c} 1 \mathrm{p} 3$ & $3,5 \%$ & $8 \%$ & $6 \%$ \\
\hline 3 & $\mathrm{c} 2 \mathrm{p} 2$ & $3,5 \%$ & $8 \%$ & $5 \%$ \\
\hline
\end{tabular}

Berdasarkan Tabel 8, dapat dilihat bahwa nilai kadar air pada kopi instan tanpa menggunakan edible packaging cenderung naik selama waktu penyimpanan. Naiknya kadar air dapat disebabkan adanya permeabilitas bahan kemasan produk terhadap uap air, 
sifat bahan-bahan yang terdapat pada produk kopi instan yang higroskopis sehingga cenderung mengadsorbsi uap air dari udara, dan tingkat kelembaban udara lingkungan terhadap produk. Pada kopi instan dengan menggunakan edible packaging kode c1p2 dan c1p3 menunjukan peningkatan kadar air sebesar 2,5\%, sementara pada kopi instan dengan menggunakan edible packaging kode c2p2 menunjukan peningkatan sebesar $1,5 \%$. Hal ini dapat terjadi karena adanya sifat permeabilitas bahan kemasan terhadap uap air. Meningkatnya sifat permeabilitas ini akan membuat semakin banyak uap air dari lingkungan yang melewati bahan kemasan. Sifat produk kopi instan yang higroskopis akan menyebabkan produk menyerap uap air yang telah melewati bahan kemasan tersebut.

Berdasarkan hasil penelitian, maka dapat diambil kesimpulan sebagai berikut :

1. Konsentrasi CMC berpengaruh nyata terhadap kadar air, kecepatan larut, tekstur dan warna, namun tidak berpengaruh nyata terhadap kenampakan edible packaging pati kacang hijau

2. Konsentrasi gliserol berpengaruh nyata terhadap kadar air, kecepatan larut, dan tekstur, namun tidak berpengaruh nyata terhadap kenampakan dan warna edible packaging pati kacang hijau.

3. Interaksi konsentrasi CMC dan konsentrasi gliserol berpengaruh nyata terhadap kadar air, kecepatan larut, dan tekstur namum tidak berpengaruh nyata terhadap kenampakan dan warna edible packaging pati kacang hijau.

4. Pada penelitian pendahuluan diperoleh hasil uji kadar air pati kacang hijau yaitu sebesar $5,5 \%$, kadar pati dari pati kacang hijau sebesar $87,59 \%$ dan plasticizer gliserol memiliki nilai persen elongasi terbesar yaitu $470 \%$, nilai kuat tariknya sebesar $1,46755 \mathrm{MPa}$, serta kecepatan larut $0,0139 \mathrm{~g} /$ detik sehingga penggunaan plasticizer gliserol dipilih sebagai bahan plasticizer untuk perlakuan pada penelitian utama.

5. Perlakuan terpilih dari penelitian utama adalah perlakuan c1p2 dengan konsentrasi CMC $1 \%$ dan konsentrasi gliserol 2\%, c1p3 dengan konsentrasi CMC $1 \%$ dan konsentrasi gliserol 3\%, dan $\mathrm{c} 2 \mathrm{p} 2$ dengan konsentrasi CMC $2 \%$ dan konsentrasi gliserol $2 \%$.

6. Hasil analisis fisik sampel terpilih c1p2 memiliki nilai kuat tarik 2,48193 $\mathrm{MPa}$, persen elongasi sebesar $70 \%$ dan laju transmisi uap air sebesar 0,172522 (g/m2/h), c1p3 memiliki nilai kuat tarik 3,94362 MPa, persen elongasi sebesar $37 \%$ dan laju transmisi uap air sebesar 0,195397 $(\mathrm{g} / \mathrm{m} 2 / \mathrm{h})$ dan c2p2 memiliki nilai kuat tarik 1,093815 MPa, persen elongasi sebesar $106 \%$ dan laju transmisi uap air sebesar 0,157729 (g/m2/h).

\section{Daftar Pustaka}

1. AOAC. 2000. Official Methods of Analysis. Association of Official Analytical Chemists. Benjamin Franklin Station, Washington DC. 17th Edition. 1st Revison.
2. ASTM. 1980. ASTM D638-94. Standard Test Method for Tensile Properties Plastic, Annual Book od ASTM Standard. Philadelphia. American Society for Testing and Materials.

3. Asaoka, M., Okuno, K. dan Fuwa, H. (1985). Effect of environmental temperature at the milky state on amylose content and fine structure of waxy and nonwaxy endosperm starches of rice (Oryza sativa L.). Agricultural and Biological Chemistry. 49: 373376

4. Ban, W. 2006. Influence of natural biomaterials on the elastic properties of starch-derived films: An optimization study. Journal of Applied Polymer Science. 15: 30-38.

5. Bourtoom, T. 2007. Effect of Some Process Parameters on The Properties of Edible Film Prepared From Starch. Department of Material Product Technology, Songkhala

6. Clifford, M.N. dan K.C. Willson. 1985. Coffee Botany Biochemistry and Production of Beans and Beverage. The AVI Publishing Company, Inc. Westport, Connecticut.

7. Damat. 2008. Efek Jenis Dan Konsentrasi Plasticizer Terhadap Karakteristik Edible Film Dari Pati Garut Butirat. Agritek 16(3): 333-339

8. Garcia, M.A., M.N. Martino and N.E. Zaritzky. 2000. Lipid Addition To Improve Barrier Properties Of Edible Film Starch-Based Film and Coatings. J.Food Science. 65 (6):941-947.

9. Gontard, N., Guilbert, S., Cuq, J. 1993. Water and Glycerol as Plasticizers Affect Mechanical and Water Vapor Barrier Properties of An Edible Wheat Gluten Film. Journal Food Science. 58, 206 -211 .

10. Indriyati, Lucia Indrarti dan Rahimi. 2006. Pengaruh Carboxymethyl Cellulose (CMC) dan Gliserol Terhadap Sifat Mekanik Lapisan Tipis Komposit Bakterial Selulosa. Jurnal Sains Materi Indonesia, vol. 8, hal: 40-44.

11. Jayeng Laga. 2017. Karakterisasi Fisiko-Kimia Biji Dan Pati Kacang Hijau (Phaseolus radiatus L.) Asal Kabupaten Kebumen Jawa Tengah Serta Aplikasinya Pada Produk Sohun. Skripsi Teknologi Pangan dan Hasil Pertanian. UGM. Yogyakarta

12. Krochta, J.W. and De Mulder-Johnston, C. 1997. Edible And Biodegradable Polymer Film: Challenges And Opportunities. J. Food Tech. 51 (2): 61-74.

13. Maizura, M., A. Fazilah, M.H. Norziah, and A.A. Karim. 2007. Antibacterial activity and mechanical properties of partially hydrolyzed sago starch alginate edible film containing lemongrass oil. $\mathrm{J}$. Food Sci. 72: 6:c324-c330

14. Manab, A. 2008. Pengaruh Penambahan Minyak Kelapa Sawit Terhadap Karakteristik Edible Film Protein Whey. Jurnal Ilmu dan Teknologi Hasil Ternak. 
15. Martaningtyas, D. 2004. Potensi Plastik Biodegradable. http://www.pikiranrakyat.com/cetak/0904/02/cakrawala/lainnya06.htm . Diakses: 14 Agustus 2019.

16. McHugh, T. H., Krochta, J, M. 1994. Permeability Properties of Edible Film. Di dalam Krochta, J.M., E.A. Baldwin and M.O Nisperos Carriedo. Edible Coating and Film to Improve Quality. Technomic Publising Co. Inc, Pensylvenia. Vol. 59.

17. Mindarwati, E. 2006. Kajian Pembuatan Edible Film Komposit Dari Karagenan Sebagai Pengemas Bumbu Mie Instant Rebus. Tesis. Program Studi Teknologi Pasca Panen pada Program Pascasarjana. Institut Pertanian Bogor.

18. Morrison W. R., Azudin M. N. 1987. Variation in the amylose and lipid contents and some physical properties of rice starches. J. Cereal Sci 5:35-39.

19. Nasaputra, M.A. 2012. Pengaruh Konsentrasi Pati Jahe Emprit (Zingiber officinale var. Rubrum) dan Asam Stearat terhadap Karakteristik Fisik, Kimia, dan Organoleptik Edible Film. Skripsi. Universitas Brawijaya. Malang.

20. Nasution, M. E. U., Hasnelly., Ina, S. N. 2014. Pemanfaatan Whey Susu Menjadi Edible Film Sebagai Kemasan Dengan Pengaruh Penambahan CMC, Gelatin Dan Plasticizer. Skripsi. Fakultas Teknik, Universitas Pasundan, Bandung

21. Nugroho, A. A., Basito dan R. Basito dan R. B. Katri. 2013. Kajian Pembuatan Edible Film Tapioka dengan Pengaruh Penambahan Pektin Beberapa Jenis Kulit Pisang Terhadap Karakteristik Fisik dan Mekanik. Jurnal Teknosains Pangan. Hal:73-79.

22. Nurhayati, Y.T., Widyaningsih, S., \& D. Kartika. 2012. Pengaruh Penambahan Sorbitol dan Karbonat Terhadap Karakteristik dan Sifat Biodegradable Film dari Pati Kulit Pisang. Molekul, 7(1): 69-81.

23. Rindlay-Wastling, A., M. Stading, A.M. Hermasson, and P. Gatenttolm. 1998. Structure, mechanical barrier properties of amylose and amylopectin films. Carbohydrate Polymer 31: 21-24.

24. Rodriguez M., Oses J., Ziani K., Mete J, I. 2006. Combined Effect of Plastizers and Surfactants on the Physical Properties of Starch Based Edible Film. Journal Food Research International. 39: 840646.

25. Setiani, W., Sudiarti, T., Rahmidar, L. 2013. Preparasi Dan Karakterisasi Edible Film Dari Poliblend Pati Sukun-Kitosan. Jurnal Valensi, 3(2), 100-109.

26. Setyani, S. 2002. Teknologi Pengolahan Kopi. Fakultas Pertanian. Universitas Lampung. Bandar Lampung. Hlm 60.

27. Soekarto, S.T. 1985. Penilaian Organoleptik untuk Industri Pangan dan Hasil Pertanian. Bhratara Karya Aksara. Jakarta.
28. Syamsir, E. 2008. Mengenal Edible Film. http://id.shvoong.com. Diakses 14 Agustus 2019.

29. Triwitono, P., Marsono, Y., Murdiati, A., Marseno, D, W., Isolasi dan Karakterisasi Sifat Pati Kacang Hijau (Vigna radiata L.) Beberapa Varietas Lokal Indonesia. Jurnal Agritech Vol. 37, No. 2 Mei 2017

30. Winarno, F.G. 2004. Kimia Pangan dan Gizi. Gramedia Pustaka Utama. Jakarta 